\title{
Fourth Latin American Labor History Conference
}

\author{
John D. French \\ Utah State University
}

Sponsored by the Latin American studies programs of Yale and the University of Connecticut, the conference on "Women and Labor in Latin America" examined the gender dynamics of production and reproduction. The presentations, given April 17-18, 1987, touched on a broad spectrum of topics, including women and factory labor, the sexual politics of rural social conflict, the tensions of life among nineteenth-century domestic servants, and women's role in contemporary trade unionism.

Dealing with employer visions of the "ideal" industrial employee, Barbara Weinstein explored the contradictions inherent in the annual industrialistsponsored Operário Padrão (Ideal Worker) campaigns conducted in São Paulo, Brazil between 1964 and 1986. Conducted by the Social Service of Industry (SESI), this factory, state, and national-level competition was designed to celebrate individual-worker achievement and foster a mobility myth within the factory, and was referred to as the Operário Ladrão (Worker Thief) or Operário Patrão (Worker Boss) contest by union activists. Only three of the 55 winners examined by Weinstein were women, despite an industrial work force that was one-quarter female.

Susan Besse of City University of New York emphasized that the male ideal underlying the SESI contest clearly implied a larger employer vision of women's proper role. Discussing the stereotyped vision of women's place advanced by the Labor Ministry in the 1930s ("efficiency, economy, and Taylorism in the kitchen"), she suggested ways to explore the differential normative standards of gender that characterized SESI and the male factory workers who voted in these contests. Steven Stein (University of Miami) welcomed Weinstein's use of interviews and work histories to examine the human-level contradictions of these "ideal workers," who tended on the whole to be male supervisory personnel.

In "Women and Popular Politics in Postwar São Paulo, Brazil," John French (Utah State University) explored women's sociopolitical participation in the industrial ABC region of Greater São Paulo, 1945-47. Dealing with a period of political upsurge and mass strikes, he observed that "the greater the extent, depth, and intensity of working-class mobilization, the greater the involvement and visibility of working-class women, including both housewives and women workers." Such abnormal times, he continued, help to reveal the

(C) 1988 by the Board of Trustees of the University of lllinois 
interconnections between different dimensions of working-class life-family and home, workplace and union, community and politics. Providing detailed information on voting and housewives' neighborhood activism, French examined female work force participation, women's role in strikes, and the biographies of leftist female leaders in ABC.

Welcoming French's disaggregated treatment of working-class women, Margaret Keck (Yale University) cautioned against leaving the impression that the "class becomes whole when women join it." For Steven Stein, French's argument about gender and class was analogous to that in the classic 1953 film Salt of the Earth (now available on video), in which women gain power, not without conflict, during a Mexican-American miners' strike. Does the interdependence of male and female in the household and workplace, Stein asked, lead to a consensus that gives less priority to women's issues specifically?

In "Playing it Safe: Defiance and Conformity Among Servant Women in Nineteenth-Century Rio de Janeiro," Sandra Lauderdale Graham (University of Texas at Austin) provided a richly detailed account of the personal lives of Rio's largest group of working women. Emphasizing the cultural dimension, she explored the opposing poles of resistance and conformity, symbolized by the annual Carnaval celebration on one hand, and concern for respectability through marriage and family on the other. The paper was notable for its discussion of women's health and child-bearing responsibilities, a surprisingly neglected area of research on women.

In dealing with the tertiary sector (the chosen focus of the $1989 \mathrm{LALH}$ conference), Graham tackled a central problem in Latin American society and politics. Recasting the discussion of resistance, Emilia Viotti da Costa (Yale) argued persuasively for an emphasis on the day-to-day conflict between servant and mistress over property, time, space, and sex. Under such face-to-face conditions of intense intimacy, da Costa observed, confrontations can be far more bitter than in any other form of social conflict. In related comments, Stein argued that attachment to family and marital respectability, when it did exist, could be seen by servants as a form of resistance to and even defiance of their superiors.

In "Incautious Women and their Bastard Children: Patriarchy in Crisis and the Roots of Rural Rebellion in Central Colombia, 1900-1930," Michael Jiménez (Princeton) examined the state of fractured patriarchy to be found in the frontier region of Viota, Cundinamarca. The structure of coffee production, he argued, initially provided an economic foundation for female autonomy in an area without coherent nuclear families controlled by men. In his wideranging paper, Jiménez discussed women's independent role in local economic life, the meaning of widespread illegitimacy, and women's role in the leadership of peasant resistance.

The paper's most provocative thesis dealt directly with the sexual politics of landowner/peasant conflict. Examining forms of sexual intimacy between 
male landowners and peasant women, Jiménez discussed practices ranging from rape and forms of sexual tribute to less coercive and more ambiguous sexual relationships. Not all such liasons were necessarily coercive he stressed, or without a certain unequal reciprocity. The outrage of peasant males at the sexual violations of peasant women, Jiménez concluded, was far from peripheral to the "real issues" of economics and power. Indeed, in 1928 the Viota peasant league demanded an end to such forms of sexual aggression by elites and their collaborators.

Stein hailed Jiménez's treatment of the cooptive and oppressive aspects of these unequal sexual relationships, though he questioned the paper's argument that sexual coercion was "perhaps the most powerful weapon at the disposal of the planters." The explosive impact of such practices, he argued, suggests that sexual abuse may in fact have been dysfunctional. To the extent that class confrontations are conducted as clashes between men, French suggested, then sexual aggression by superiors can become an important flash point of conflict, since such behavior violates the patriarchal norms shared by both sides.

In a wonderfully detailed paper on "Machismo and Women in Contemporary Guatemalan Trade Unionism," Deborah Levenson (New York University) explored the lives of specific women trade unionists under terroristic conditions. She argued that while the dominant model of trade unionist behavior coincides with male roles, it contradicts female roles and forces the minority of women unionists to carry on two struggles simultaneously. She found a feminist consciousness in female union leadership but as yet no feminist organization or challenge to the family as an institutuion.

Finding analogies in his Nicaraguan research, Jeffrey Gould (Yale) argued that a shift from male to female leadership may lead to a greater degree of democracy and less mystification of leadership per se. Several questions were raised about the impact of such female participation on their male compatriots. Were women perhaps being mobilized, Susan Besse asked, to change society while leaving male power untouched? Another participant asked if forms of patriarchy varied from one type of work place to another. Several participants called for further studies of the family and asked how mother/ child relationships fit into gender dynamics.

Participants were pleased with a conference that was neither too critical to be friendly nor too friendly to be critical. They decided to focus the Fifth Latin American Labor History Conference on "Ethnicity, Community, and Labor." The meeting will include papers dealing with black and white workers in post-emancipation São Paulo, class divisions within Italian immigrant communities in Argentina, ethnicity and struggle in rural Nicaragua, and workingclass identities in a meatpacking community in twentieth-century Argentina. 